\title{
Functional Simulation of the Method for the Coal Preparation for Combustion in the Thermal Power Plant
}

\author{
Natalia Vasilievna Fedorova, Vasily Alexandrovich Mokhov \\ and Elena Alexandrovna Krivobok
}

Platov South-Russian State Polytechnic University (NPI)

DOI: http://dx.doi.org/10.13005/bbra/1944

(Received: 18 September 2015; accepted: 26 October 2015)

\begin{abstract}
Russia's energy policy for the coming years provides for greater use of coal fuel, combined with the introduction of non-waste technologies of its combustion. Russia has taken to burn coal with ash content of various indicators, including those of high. The question of efficient use of coal in thermal power plants (TPP) of Russia by his deep preparation for burning is considered in this article. One way to solve of this problem is the construction of modern coal preparation factory directly or near the power plant. The criteria of efficiency of coal combustion are systematized. The modern methods of mineral raw materials enrichment used in the mining, metallurgical and chemical industries are considered. The parameters of coal preparation equipment offered in the Russian market by manufacturers from different countries are investigated. The systematic analysis of production processes in the TPP by functional modeling techniques based on IDEF0 diagrams and hierarchies analysis of T. Saaty is performed, allowing to prove the correctness of the proposed solution of the problem of coal enrichment in TPP prior to combustion and to provide an option of the technological chain of operations performed. The technical and economic effect after object modernization is defined. Coal deep preparation for burning, including the introduction of coal preparation factory on TPP, will create the environmentally friendly technology of fuel and energy coal-fired complex.
\end{abstract}

Key words: High ash content coal, coal preparation, activation of combustion, analysis of technological processes, systems analysis, process modeling, rating.

Russia's energy policy ${ }^{1}$ provides for greater use of coal fuel, combined with the introduction of non-waste technologies of its combustion.

According to the Russian National Standards, the ash-content of coking coal shall not exceed 5-6\%, and the ash-content of the steam coal shall amount to $13-18 \%^{2-3}$. The reduction of the ash content of the coal (coal preparation), supplied for the burning, should be based on the feasibility study and be profitable for the electricity and heat manufacturers.

Since the end of $\mathrm{XX}$ century the

* To whom all correspondence should be addressed. systematic analysis has become the main approach to solve the complex problems. Its application is the basis for a logical and consistent problem detection and validation of the proposed solutions. One of the modern tools of systems analysis for solving the problems of reengineering is a functional simulation using the appropriate computer technology and software ${ }^{4}$. The validity of the application of the functional simulation technology, in particular, is confirmed by ISO 9000 Standards.

Common approaches to coal combustion in the Russian Federation and in the world

According to the first approach, the coal preparation is inefficient, since modern thermal power plant boilers are able to use coal of any quality index. According to the second approach, 
the feasibility of coal preparation is justified by the increase in TPP electricity production efficiency and depends on many specific factors: the ash and sulfur content, the fuel, transport and coal preparation costs, the environmental protection standards, performance and availability of boilers, etc. ${ }^{5}$.

In Germany the combustion of coal with ash-content greater than $2 \%$, is prohibited by the Law. Nowadays, in all industrialized countries 70$90 \%$ of all mined stone coal is subject to coal preparation: in the FRG $-95 \%$, in the UK $-75 \%$, in the USA $-55 \%$ of coal are subject to coal preparation. South Africa and Australia, preparing $100 \%$ of the exported coal, are the world leaders in coal preparation ${ }^{6}$.

The increase in ash-content of the lowgrade fuel by $1 \%$ is:

a) the loss of power, the reduction of efficiency factor by $0.1-0.15 \%$;

b) the need for additional fuel $0.5 \mathrm{~g}$ c.t./kWh;

c) the additional suspension in production equal to 60 hours per year for repair of the equipment;

d) the installation of additional equipment for the fuel preparation and ash and slag removal, the increase in capital expenditures;

e) the increase in the electricity consumption for own needs by $0.13 \%$;

f) the increase in fuel oil consumption per unit of fuel combusted by $0.6-1.5 \%$.

Numerous studies have conclusively proven the benefit of use of the prepared coal in the energy production industry ${ }^{7-8}$.

It was found that the elimination of reduced production of electricity at TPP due to a poor coal could cover all the coal preparation costs, even without so much as the benefit from environmental improvements ${ }^{9}$.

The construction of modern coal preparation plant located near or directly at the TPP is one of the ways of solving this problem ${ }^{10}$. Functional simulation of the production processes

In 1993, the project was developed and the Standard for the functional simulation (IDEF0) was adopted to meet the challenges of this type ${ }^{11}$. Since the beginning of the XXI century the IDEF0 methodology is used as the primary standardization tool in the domestic economy ${ }^{12}$.
The IDEF0 language is standardized in terms of syntax and semantics. The IDEF0 models are three-dimensional, as any two-dimensional IDEF0 diagram can be supplemented by the child functions represented in different layers or levels of the model. The restrictions on the number of child functional layers in the IDEF0 model are absent.

The IDEF0 models are developed and used by the system engineers for simulation and analysis of the complex systems, functional studies of production processes, etc. A number of examples, demonstrating the operational use of IDEF0 are provided both in the domestic and foreign literature ${ }^{13-15}$.

In preparing the materials for this article the tools of the free package Ramus Educational [16], similar to AllFusion Process Modeler 7 (formerly BPwin) were used.

The aim of this work is to prove the correctness of the proposed solution of the problem of coal preparation at TPP prior to combustion and to provide an option of the technological chain of operations performed. The solution to these problems has been obtained on the basis of the methodology of functional simulation IDEF0, which is widely used for different types of the systems ${ }^{17}$.

The traditional scheme of the construction of the "correct" technological process model was used in this work, according to which the transition from the AS-IS model to TO$\mathrm{BE}$ model was performed ${ }^{18}$.

Other methods of systems analysis can be used to solve such problems: the evolutionary algorithms for optimal solutions finding ${ }^{19}$, the multiagent simulation ${ }^{20}$, the parametric optimization $^{21}$, as well as the widespread methods of computational mathematics and mathematical physics ${ }^{22}$.

\section{Criteria for the coal combustion efficiency}

The integrated approach allows to select a group of criteria for the coal combustion efficiency, represented in the Table 1 . The increase in the coal combustion efficiency can be achieved at the expense of its deep preparation for combustion, including the coal preparation and supplementation to activate the process of combustion and disposal of the emissions. 
Analysis of the methods of mineral raw materials preparation

The preparation processes are relevant to the mining, metallurgical and chemical sectors of industry ${ }^{23-24}$. All methods of preparation are based on the differences in physical and chemical properties of the substances. The first scientific works on mineral raw materials preparation were related to the extraction of the metal ores. Agricola ${ }^{25}$ in particular, studied the mechanical methods of preparation such as crushing, washing, and the thermal methods - melting in special furnaces. Lomonosov $^{26}$ investigated the separation of the metals from the ores by melting. Modern methods of preparation of the minerals are presented in the Table 2.

\section{Analysis of the technological processes}

In the late 90-ies of the XX century, most of the coal preparation plants in Russia were closed. This led to a sharp increase in the ash-content of the coal combusted. This situation provides extremely negative impact not only on the performance of the thermal power plants, but also on the environment nearby the power plant. In terms of the macro-economy, it is advisable to perform the coal preparation close by the places of its production with the subsequent sale to the consumers. In the context of the slow rebirth of the centralized coal preparation and sale of the non-prepared coal of variable ash-content to the consumers, it seems appropriate to the authors to include the coal preparation stage in the process of preparation of the air-coal dust mixture (Fig. 1). The proposed innovations are reflected in the diagram TO-BE of the process of coal preparation for combustion (Fig. 2). This diagram also reflects the changes in the process of supply to the boiler, associated with the deep coal preparation for combustion, including, except the preparation, the introduction of additives (activators, catalysts), activating the combustion process.

The context diagram of the TO-BE process of the coal preparation for combustion (Fig. 3), in addition to the described input, output streams and mechanisms for the implementation of the technological operations, shows a list of control and regulatory documents, setting the conditions for the implementation of the technological and logical processes, described in the model.

Table 1 . Criteria for the coal combustion efficiency.

No. Functional group of criteria Criteria

1 Performance and technology - increase in maneuverability of the power units

- extension of the adjustment range

- reduction of the requirements to the capabilities of the accessories

- reduction of the wear and tear

- extension of the time between the overhauls

2 Material and technical

- reduction of the reference fuel

- reduction of the need for additional highly reactive fuel

- reduction of excess air ratio

- reduction of the exhaust gases volume

3 Economical

- reduction of the financial costs on exploitation of TPP

- reduction of the TPP own needs costs

- reduction of the electricity cost

4 Environmental

- reduction of the amount of harmful emissions

- reduction of the thermal pollution of the atmosphere

- reduction of the soil and groundwater pollution

- change in the physical and chemical properties of the solid and liquid waste

- improvement of the environmental performance of the electricity product ion process at TPP (gassed space, noise, vibration)

5 Social

- improvement of the working conditions of the TPP staff

- creation of the preconditions for the development of the side-line product ions near TPP 
Coal preparation equipment, available on the special equipment market

The analysis of the literature and the Internet sources allowed to identify the main manufacturers of the coal preparation equipment, available on the market of the Russian Federation (Table 3).

Selection of the coal preparation plant according to the method of T. Saaty

The evaluation of the different variants of the technological equipment was performed based on the hierarchies analysis method of $\mathrm{T}$. Saaty ${ }^{27-28}$.

Proceeding from the foregoing list of equipment and its characteristics (Table 3 ) the list of alternative equipment brands including five positions was completed as follows: FGX (China), SKV (Ukraine), allair®Allmineral (Germany), Osborn (South Africa) and Sepair (Russia).

The criteria for selection of the equipment were determined on the basis of the criteria of the coal combustion efficiency (Table 1): K1 shows the efficiency (the assessment by this criterion involves the proximity of the equipment index to the desired value for the power unit of $300 \mathrm{MW}$ ); K2 shows the dimensions (the criterion is focused on the possibility to mount the coal preparation unit near the fuel and transport workshop of TPP); K3 shows the energy consumption (this criterion takes into account the consumption of the electricity by the main and auxiliary machinery of

Table 2. Methods of mineral raw materials preparation

\begin{tabular}{|c|c|c|c|c|}
\hline No. & $\begin{array}{l}\text { Used properties of } \\
\text { the minerals } \\
\text { and additives } \\
\text { to be prepared }\end{array}$ & $\begin{array}{l}\text { Groups of } \\
\text { methods of } \\
\text { preparation }\end{array}$ & Methods of preparation & $\begin{array}{l}\text { Types of methods } \\
\text { of preparation }\end{array}$ \\
\hline \multirow[t]{5}{*}{1} & \multirow[t]{5}{*}{ Physical } & Mechanical & $\begin{array}{l}\text { - milling (crushing, grinding) } \\
\text { - dispersion (screening) }\end{array}$ & $\begin{array}{l}\text { - pneumatic } \\
\text { - hydraulic-in heavy } \\
\text { medium }\end{array}$ \\
\hline & & Gravity & - gravity separation & $\begin{array}{l}\text { - pneumatic } \\
\text { - hydraulic } \\
\text { - in heavy medium }\end{array}$ \\
\hline & & Thermal & $\begin{array}{l}\text { - thermogravitational } \\
\text { - pyrometallurgical (roasting, } \\
\text { smelting, distillation) }\end{array}$ & \\
\hline & & Electromagnetic & $\begin{array}{l}\text { - electrostatic separation } \\
\text { - magnetic separation } \\
\text { - electromagnetic separation }\end{array}$ & $\begin{array}{l}\text { - pneumatic } \\
\text { - hydraulic }\end{array}$ \\
\hline & & Radiometric & - radiometric (for uranium ore) & \\
\hline 2 & $\begin{array}{l}\text { Physical and } \\
\text { chemical }\end{array}$ & $\begin{array}{l}\text { Surface phenomena, } \\
\text { wettability } \\
\text { Thermal }\end{array}$ & $\begin{array}{l}\text { - flotation } \\
\text { - thermochemical (melting with the } \\
\text { addition of reagents) } \\
\text { - Thermo electrolytic (electroly } \\
\text { sis) }\end{array}$ & \\
\hline \multirow[t]{2}{*}{3} & \multirow[t]{2}{*}{ Chemical } & $\begin{array}{l}\text { Selective chemical } \\
\text { reactions } \\
\text { Solubility }\end{array}$ & $\begin{array}{l}\text { - leaching } \\
\text { - hydraulic- thermal } \\
\text { - halurgical (solubility difference) } \\
\text { - extraction (transition in a solution) } \\
\text { - method of forming of the } \\
\text { poorly soluble compounds (pre } \\
\text { cipitation from solution) }\end{array}$ & \\
\hline & & $\begin{array}{l}\text { Other chemical pro } \\
\text { cesses }\end{array}$ & $\begin{array}{l}\text { - hydrolysis } \\
\text { - electrolysis } \\
\text { - ion exchange method }\end{array}$ & \\
\hline 4 & Biochemical & & $\begin{array}{l}\text { - bacterial } \\
\text { - microbiological }\end{array}$ & \\
\hline
\end{tabular}


the unit); K4 shows the water consumption (taking into account the need to use water resources); K5 shows the adaptation (this criterion indicates the extent to which the technology used in the unit, complies with the domestic environmental conditions and standards).

The ratings (priorities) for the criteria are set in the range of 1 to 9 where 1 means the equal importance of the criteria, 9 means a very severe superiority of one criterion over the other. The calculation results are presented in the Table 4 . The best option of the processing plant is the option number 5 (Sepair, Russia), having a maximum value of a global priority. The option number 2 (SKV, Ukraine) should be noted, which is the second (close) preferred alternative

The "Sepair" product line includes the industrial unit with the capacity of $120 \mathrm{t} / \mathrm{h}$ of raw coal, while the demand of the coal energy unit of $300 \mathrm{MW}$ is $100 \mathrm{t} / \mathrm{h}$. The coal with the original ashcontent of $22-23 \%$, class $14-25$ and $25-40 \mathrm{~mm}$ is divided by the "SEPAIR" unit in the low-ash coal (ash-content of 8-12\%), traded coal (16-18\%), middling (35\%) enclosing the high-ash solids (tailing, ash-content of $75 \%$ or more). The schematic diagram of the "Sepair" unit is shown in the Fig. 4.

Technical and economic effect of the modernization of the facility

The technical and economic analysis of the proposed solutions showed, that for $300 \mathrm{MW}$ power unit at the cost of the coal preparation unit equal to 300 million rubles, the annual fuel consumption equal to 878,400 tons and the fuel price equal to $2000 \mathrm{rub} . / \mathrm{t}$ :

a) the capital investments, including the transportation costs, building and construction works, will amount to 456 million rubles;

b) the annual operating costs, including the depreciation deductions and the cost of the annual maintenance, will amount to 41.04

Table 3. Manufacturers of the coal preparation equipment

\begin{tabular}{|c|c|c|c|c|}
\hline No. & Country of origin & Countries and regions-consumers & $\begin{array}{l}\text { Trademarks of } \\
\text { the equipment }\end{array}$ & $\begin{array}{l}\text { Web-site of the } \\
\text { supplier }\end{array}$ \\
\hline 1 & China & $\begin{array}{l}\text { China Europe, USA, Russia, Ukraine, } \\
\text { Brazil, Turkey, South Africa, Ka } \\
\text { zakhstan, Iran, North Korea, the } \\
\text { Philippines, Viet Nam, Indonesia, } \\
\text { Mongolia }\end{array}$ & $\begin{array}{l}\text { Batak, } \\
\text { Baum, } \\
\text { FGX }\end{array}$ & $\begin{array}{l}\text { Equipment from } \\
\text { China, } \\
\text { www.china-bridge.ru }\end{array}$ \\
\hline 2 & $\begin{array}{l}\text { Ukraine (Lug } \\
\text { ansk) }\end{array}$ & $\begin{array}{l}\text { Ukraine, } \\
\text { Russia }\end{array}$ & 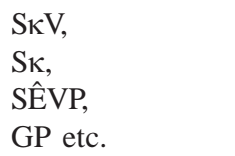 & $\begin{array}{l}\text { Alliance Oil, al } \\
\text { yansoil.co } \\
\text { m }\end{array}$ \\
\hline 3 & Germany & $\begin{array}{l}\text { Europe } \\
\text { Russia }\end{array}$ & $\begin{array}{l}\text { al } \\
\text { lair®Allmineral, } \\
\text { CETCO }\end{array}$ & $\begin{array}{l}\text { Vibrotechtsentr, } \\
\text { www.vtcenter.ru }\end{array}$ \\
\hline 4 & China & $\begin{array}{l}\text { Southeast Asia, Eastern Europe, } \\
\text { South America, Middle East, Africa }\end{array}$ & Liming & $\begin{array}{l}\text { Liming LLC, } \\
\text { Shanghai } \\
\text { Mining Machinery } \\
\text { Company, } \\
\text { fakmil.com }\end{array}$ \\
\hline 5 & $\begin{array}{l}\text { South Africa } \\
\text { (including under } \\
\text { license of Telsmith, } \\
\text { American Pulverizer } \\
\text { (USA), Mogensen } \\
\text { (United Kingdom), } \\
\text { IFE (Austria)) }\end{array}$ & $\begin{array}{l}\text { South America, Asia, Australia, Russia, } \\
\text { CIS countries }\end{array}$ & Osborn & $\begin{array}{l}\text { Ore and rock proc } \\
\text { essing, www. } \\
\text { gorniedrobilki.com }\end{array}$ \\
\hline 6 & $\begin{array}{l}\text { Russia } \\
\text { (Novosibirsk) }\end{array}$ & Russia, CIS countries & Sepair & $\begin{array}{l}\text { Gormasheksport, } \\
\text { gmexp.ru }\end{array}$ \\
\hline
\end{tabular}


Table 4. The results of the evaluation of the alternatives

\begin{tabular}{|c|c|c|c|c|c|c|c|}
\hline \multirow[t]{2}{*}{ No. } & \multirow[t]{2}{*}{ Alternatives } & \multicolumn{5}{|c|}{ Criteria } & \multirow{2}{*}{$\begin{array}{l}\text { Global } \\
\text { priorities }\end{array}$} \\
\hline & & K1 & K2 & K3 & K4 & K5 & \\
\hline \multicolumn{8}{|c|}{ The numerical value of the priority vector } \\
\hline & & 0.029 & 0.044 & 0.128 & 0.273 & 0.526 & \\
\hline 1 & FGX & 0.108 & 0.053 & 0.126 & 0.222 & 0.176 & 0.175 \\
\hline 2 & SKV & 0.065 & 0.456 & 0.118 & 0.111 & 0.313 & 0.232 \\
\hline 3 & allair®Allmineral & 0.042 & 0.089 & 0.100 & 0.222 & 0.099 & 0.130 \\
\hline 4 & Osborn & 0.108 & 0.152 & 0.095 & 0.222 & 0.099 & 0.135 \\
\hline 5 & Sepair & 0.677 & 0.250 & 0.561 & 0.222 & 0.313 & 0.328 \\
\hline
\end{tabular}

million rubles;

c) the annual savings from the reduction of the fuel consumption will be 10,600 tonnes/ year, or 21.2 million rubles;

d) the reduction of fees for sulfur oxides ${ }^{29}$ emissions will amount to 37.4 million rubles, while the volume of emissions after the event will be reduced by $50 \%$;

e) the total annual savings net annual operating costs, related to the coal

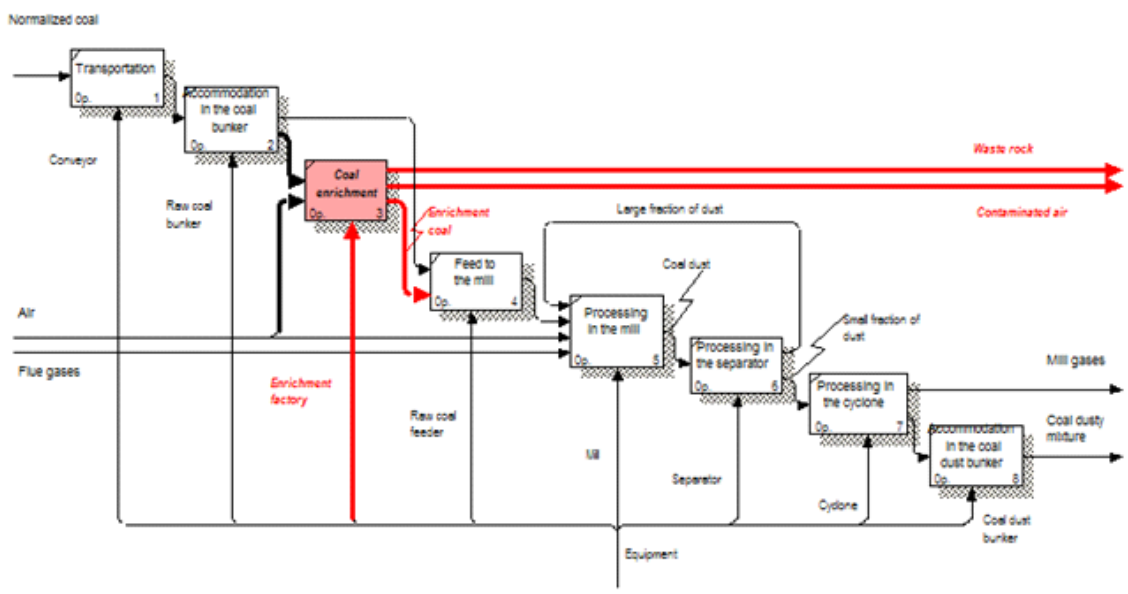

Fig. 1. Diagram of the process of preparation of the air-coal dust mixture

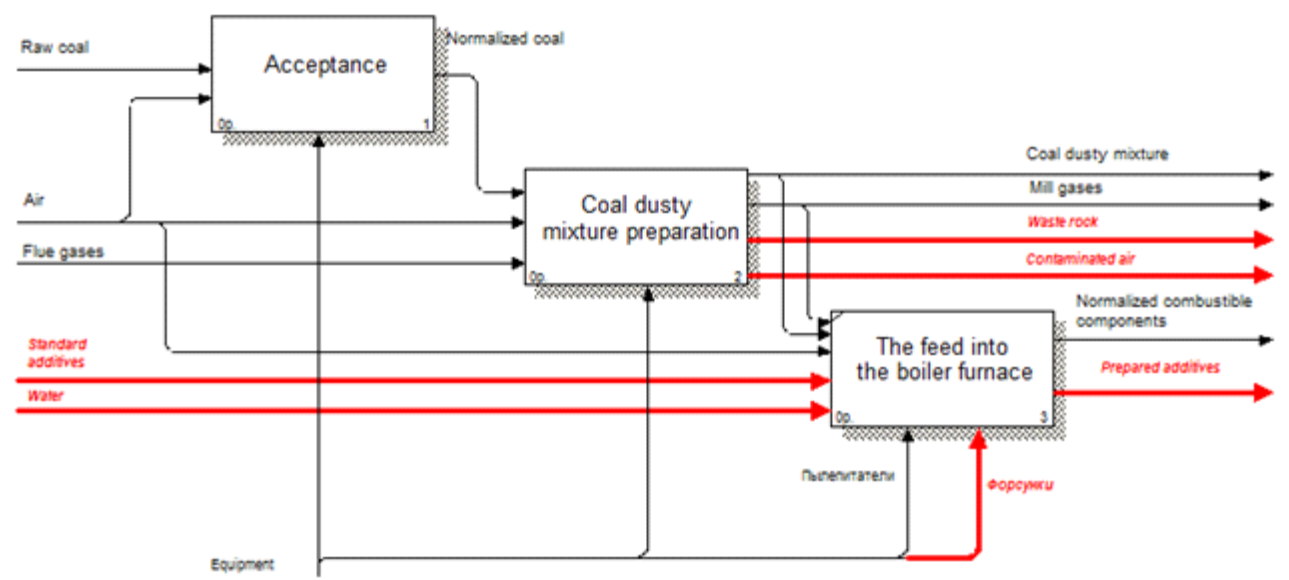

Fig. 2. Diagram of the TO-BE process of the coal preparation for combustion 


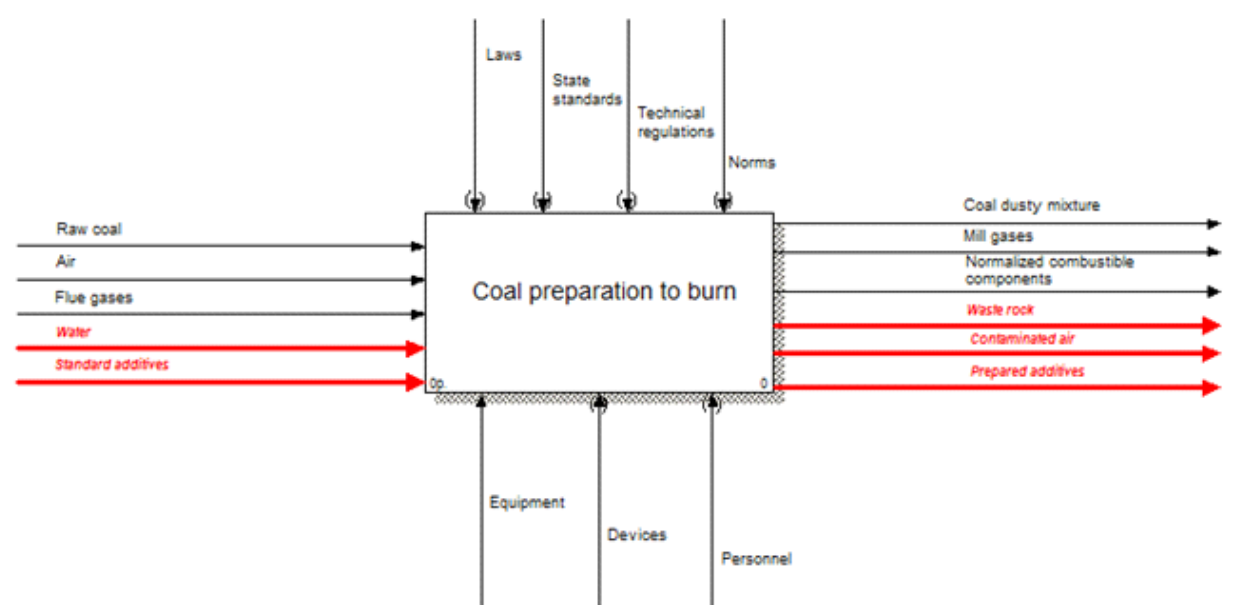

Fig. 3. Context diagram of the TO-BE process of the coal preparation for combustion

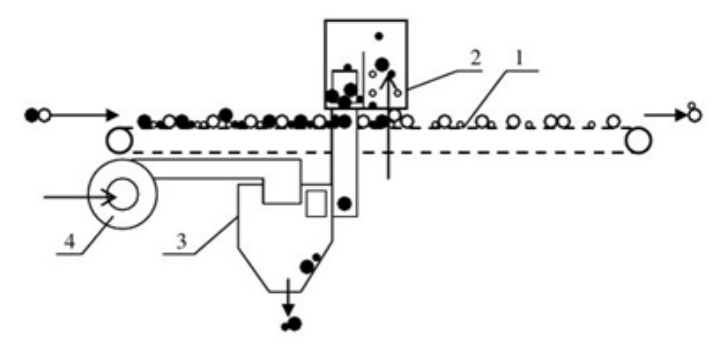

1 - belt wire-net conveyor; 2 - air nozzle;

3 - product bin; 4 - blower.

Fig. 4. Schematic diagram of the "SEPAIR" pneumatic separator

preparation unit, will be equal to 17.56 million rubles;

f) the net income, subject to tax on profits equal to $20 \%$, will amount to more than 14 million rubles;

f) the simple payback period, taking into account the net income, depreciation and amortization deductions, will be approximately 12 years from the commissioning of the coal preparation unit "SEPAIR", but in the case of a modular (simplified) performance of the coal preparation line, by reducing the time and the installation costs, the cost of the coal preparation will be reduced to 25-30 rubles per tonne of raw coal ${ }^{30}$, which will allow to reduce the payback period to 2 years.

\section{CONCLUSIONS}

\section{Recommendations}

To solve the problem of high-ash coal combustion efficiency improvement at the thermal power plants it is necessary to develop a new approach to the evaluation of the coal washability as well as the concept of rational use of the steam coal, defining the fundamental improvement in the efficiency of the coal power by the substitution of the mine coal by the prepared coal in the fuel balance of the thermal power plants and the high competitiveness of the prepared coal fuel, commensurate with the other organic energy carriers. These measures will allow to create the technology of environmentally friendly coalburning fuel and energy complexes. To this end, the authors plan the further development of the simulation models, based on the agent approach to the thermal power plants for the rapid assessment of the effectiveness of the solutions, similar to the solutions, proposed in this work, for the specific power plants, and, possibly, the regions.

The work was financially supported by the Ministry of Education and Science of the Russian Federation in the framework of the implementation of the FTP "Research and development on the priority development fields of the scientific and technological complex of Russia for 2014-2020” (Agreement No 14.574.21.0018 on "Development of the method for the intensification 
of the low-reactive coal gasification process in an upward jet-vortex of the oxidant.” Unique identifier PNI (of the Project) RFMEFI57414X0018).

\section{REFERENCES}

1. Energy Strategy of Russia until 2030 (App. to the public and business magazine "Energy Policy”) (p. 184). (2010). Moscow: Institute of Energy Strategy.

2. GOST R 51586-2000. Brown Coals, Hard Coals and Anthracites of Kuznetsk and Gorlovky Basins for Power Supply Purposes. Specifications. (2000). Retrieved June 5, 2015, from http://docs.cntd.ru/document/1200026841.

3. GOST 17321-71. Coal. Preparation. Terms and Definitions. (1971). Retrieved June 5, 2015, from http://standartgost.ru/.

4. Cheremnyh, S.V., Semenov, I.O., \& Ruchkin, V.S. (2002). Simulation and Systems Analysis: IDEF-Technology: Practical Course (p. 192). Moscow: Finance and Statistics.

5. Holt, E.C. Jr. (1982, May). Effect of Coal Quality on Maintenance Costs of Utility Plants. American Mining Congress Journal.

6. The Official Website of Mining Industry Journal. (n.d.). Retrieved June 6, 2015, from http://www.mining-media.ru/.

7. SibAcademInnovatsiya website. (n.d.). Retrieved June 6, 2015, from http:// www.sibai.ru/.

8. Burdukov, A.P., Popov, V.I., Faleev, V.A., \& Yusupov, T.S. (2010). The Use of the Mechanically Activated Coal of Micropulverisation in the Energy Sector. Polzunovskiy Vestnik, 1, 93-98.

9. Gorshkov, A.S. (1983). The National Economic Damage Caused by the Deterioration of the Steam Coal Quality and Coal Preparation Efficiency. Electricheskie stantsii, 9, 2-4.

10. Fedorova, N.V., \& Krivobok, E.A. (2015). Preparation of High-Ash Coals to Combustion at the Thermal Power Plants. Ecologiya Promishlennogo Proizvodstva, 1(89), 41-46.

11. Air Force Wright Aeronautical Laboratories. (1981). ICAM architecture. Part II, Volume IV. Function modeling manual (IDEF0). Ohio: Air Force Systems Command, Wright-Patterson Air Force Base.

12. Methodology for Functional Simulation. (2000). Moscow: Rossiyskiy Gosudarstnenniy Standart.

13. Komissarova, M.A., \& Leonova, S.A. (2014). Improvement in the Effectiveness of the Coal Mining Companies Based on the Process
Simulation. Gorniy Informatsionnoanaliticheskiy Bulleten, 8, 227-284.

14. Cochran, L., \& Wheaton, K. (2002). A Conceptual Operational Model for Command and Control of International Missions in the Canadian Forces. Ottawa: FirstMark Technologies Ltd.

15. Selivanov, S.G., \& Gavrilova, O.A. (2014). Development of the Innovative Methods of Production and Optimization Methods for the Aircraft Engine Technology. Vestnik UGATU, 4(64), 61-71.

16. Ramus - a Cross-Platform System for Simulation and Analysis of Business Processes. (n.d.). Retrieved July 5, 2015, from http:// ramussoftware.com/.

17. National Institute of Standards and Technology. (1993). Announcing the Standard for Integration Definition for Function Modeling (IDEF0).

18. Waissi, G.R., Demir, M., Humble, J.E., \& Lev, B. (2015). Automation of Strategy Using IDEF0 - A Proof of Concept. Operations Research Perspectives, 2, 106-113.

19. Kuznetsova, A.V., Mokhov, V.A., \& Turovskaya, E.V. (2014). Simulation of Optimal Placement of Goods at the Self-Service Stock Based on the Evolutionary Search Algorithms. Inzhenerniy Vestnik Dona, 1. Retrieved August 25, 2015, from http://www.ivdon.ru/magazine/archive/ n1y2014/2276.

20. Mokhov, V.A., Gheorghitsa, I.V., \& Goncharov, S.A. (2013). Multi-Agent Simulation of the Network Attack Such as DDoS. Inzhenerniy Vestnik Dona, 3. Retrieved August 25, 2015, from http://ivdon.ru/magazine/archive/n3y2013/ 1852.

21. Mokhov, V.A, \& Borodulina, E.N. (2014). On the Issue of Parametric Optimization of the Swarm Algorithms. Izvestiya SFU. Technicheskie nauki, 4, 230-234.

22. Efimov, N.N., \& Tyrnikova, U.V. (2007). Method of Calculation of the Temperature Field of the Fin Tubes of the Evaporator Heating Surfaces of the Boilers. In Improving the Efficiency of the Electricity Production: Materials of the VI International Scientific and Engineering Conference (pp. 240-243). Novocherkassk: Onyx +.

23. Promyshlennaya ekologiya website. (n.d.). Retrieved June 5, 2015, from http://promecologi.ru/.

24. Vse o Gornom Dele website. (n.d.). Retrieved June 5, 2015, from http://computerchoppers.ru/

25. Agricola, G.O. (1986). On Mining and Metallurgy (p. 292). Moscow: Nedra. 
26. Lomonosov, M.V. (1763). The Fundamentals of Metallurgy or Mining (p. 436). St. Petersburg: Publ. House of the Imperial Academy of Sciences.

27. Saaty, T.L. (2008). The Decision-Making at the Dependencies and Feedback: Analytical Networks (p. 360). Moscow: Pubishing house LKI.

28. Saaty, T.L. (1987). Concepts, Theory and Techniques: Rank Generation, Preservation and
Reversal in the Analytic Hierarchy Process. Decision Sciences, 18, 157-177.

29. Novikova, Zh.I. (2008). How to Calculate the Cost of Pollution. Rossiyskiy Nalogoviy Kurier, 6. Retrieved June 6, 2015, from http://e.rnk.ru/ article.aspx?aid=231984.

30. Dry Preparation - SEPAIR Air Separation Unit. (n.d.). Retrieved November 6, 2015, from http:/ /gmexp.ru/equipment/type/grav/sepair.html. 